\title{
Cervical cancer among Aboriginal women in Canada
}

\author{
Alain A. Demers PhD, Erich V. Kliewer PhD, Olivia Remes BSc, Jay Onysko BA MA, Katherine Dinner MSc, \\ Tom Wong MD MPH, Gayatri C. Jayaraman MPH PhD
}

I

f cervical cancer is diagnosed early and treated, the chances of a cure are very high. The Papanicolaou (Pap) test is used to detect abnormal cells that could indicate cervical cancer. Routine Pap testing is one of the pillars promoted to prevent cervical cancer. Measuring participation in screening for cervical cancer is a critical indicator of the success of prevention efforts. Rates of screening have historically been low among Aboriginal women (Metis, Inuit and First Nations) in Canada. ${ }^{1,2}$

A summary of the results of several Canadian studies about the rates of screening in Aboriginal populations is available in Appendix 1 (available at www.cmaj.ca/lookup/suppl/doi:10.1503 /cmaj.110523/-/DC1). High rates of screening (75\%-87\%) have been reported in both Aboriginal and non-Aboriginal groups in surveys by Statistics Canada, although the results varied as to which group had the highest rate..$^{3-6}$ The 2002/03 First Nations Regional Longitudinal Health Survey ${ }^{7}$ reported screening rates for cervical cancer among First Nations women that were comparable with those reported in the rest of the Canadian population. ${ }^{4}$ More recently, in 2005, a large proportion of women in Nunavik reported having had a Pap smear in the previous two years (72\% among 18-24 year olds, $85 \%$ among 25-34 year olds, 80\% among both 35-44 and $45-54$ year olds, and $71 \%$ among 55-65 year olds), ${ }^{8}$ and in the previous three years $\left(77 \%, 84 \%, 62 \%, 70 \%\right.$ and $67 \%$, respectively). ${ }^{9}$ These rates are close to those reported for women in the general Canadian population. ${ }^{4}$ This pattern was also observed among Metis women in Manitoba, who were reported as having a comparable rate of screening for cervical cancer with other women in the province..$^{10}$

In 2002, the National Aboriginal Health Organization conducted a telephone survey with First Nations people across Canada to measure, among other things, the use of preventive health services. They found that $50 \%$ of First Nations women living on or near a reserve reported receiving at least one Pap test in the previous year. ${ }^{11}$ Within small communities in the Northwest Territories, a similar rate of screening was reported among Aboriginal (71.9\%) and nonAboriginal (74.8\%) women. In contrast, in Yellowknife, Aboriginal women had a lower screening rate than non-Aboriginal women $(71.1 \% \mathrm{v}$. $92.0 \%){ }^{12,13}$ These latter results suggest that the challenges for seeking and obtaining screening for cervical cancer may be different between Aboriginal and non-Aboriginal women and may be related to location.

As we have shown there have been improvements in the uptake of Pap testing among Aboriginal women, although the reported rates of invasive cervical cancer among Aboriginal women in Canada have historically been 1.73.5 times higher than among other groups of Canadian women. In addition, mortality associated with cervical cancer has been up to four times higher among Aboriginal women than among non-Aboriginal women. ${ }^{14}$ We do not know if the improvement in the reported rates of screening among Aboriginal women will translate to reduced incidence and mortality. Efforts to bridge the gap in the incidence of cervical cancer and its associated mortality between Aboriginal and non-Aboriginal women may benefit from collaborative work across several fronts, including the promotion of culturally appropriate educational materials and services related to sexual health, screening for cervical cancer, and immunization against human papillomavirus. Research on human papillomavirus and related outcomes among Aboriginal populations will also help address the current gaps in knowledge.

\section{- KEY POINTS}

- Historical data suggest that fewer Aboriginal women than nonAboriginal women receive screening for cervical cancer in Canada.

- However, recent data indicate that this may no longer be true.

- We do not know if increased screening among Aboriginal women will translate to reduced incidence of cervical cancer and associated mortality. 


\section{References}

1. Young TK, Kliewer E, Blanchard J, et al. Monitoring disease burden and preventive behavior with data linkage: cervical cancer among aboriginal people in Manitoba, Canada. Am J Public Health 2000;90:1466-8.

2. Hislop TG, Clarke HF, Deschamps M, et al. Cervical cytology screening. How can we improve rates among First Nations women in urban British Columbia? Can Fam Physician 1996; 42:1701-8.

3. McDonald JT, Trenholm R. Cancer-related health behaviours and health service use among Inuit and other residents of Canada's north. Soc Sci Med 2010;70:1396-403.

4. Statistics Canada. Canadian Community Health Survey. Ottawa (ON): Statistics Canada; 2005. Available: http://estat.statcan.gc.ca /cgi-win/cnsmcgi.exe?Lang=E\&EstatFile=/ESTAT/English/CII_1 -eng.htm\&RootDir=ESTAT/ (accessed 2011 June 23).

5. Waters S. The HPV vaccine for Nunavut: a discussion paper. Iqaluit (NU): Office of the Chief Medical Health Officer, Department of Health and Social Services, Government of Nunavut; 2008.

6. Amankwah E, Ngwakongnwi E, Quan H. Why many visible minority women in Canada do not participate in cervical cancer screening. Ethn Health 2009;14:337-49.

7. Assembly of First Nations/First Nations Information Governance Committee. First Nations Regional Longitudinal Health Survey (RHS) 2002/03, results for adults, youth and children living in First Nations communities. Ottawa (ON): First Nations Centre 2007. Available: www.rhs-ers.ca/sites/default/files/ENpdf/RHS 2002/rhs2002-03-technical_report.pdf (accessed 2011 Jan. 12).

8. Louchini R, Chateau-Degat M, Brassard P, et al. Cervical cance and cervical intraepithelial neoplasia prevalence among Inuit women in Nutavik. Proceedings of the Twenty-Fourth International Papillomavirus Conference; 2007 Nov. 3-10; Beijing (China).

9. Hamlin-Douglas LK, Coutlee F, Roger M, et al. Prevalence and age distribution of human papillomavirus infection in a population of Inuit women in Nunavik, Quebec. Cancer Epidemiol Biomarkers Prev 2008;17:3141-9.

10. Martens P, Bartlett J, Burland E, et al. Profile of Metis health status and healthcare utilization in Manitoba: a population-based study. Winnipeg (MB): Manitoba Centre for Health Policy in collaboration with the Manitoba Metis Federation; 2010. Available: http://mchp
-appserv.cpe.umanitoba.ca/reference/Metis_Health_Status_Full _Report.pdf (accessed 2011 Jan. 12).

11. National Aboriginal Health Organization. What First Nations people think about their health and health care. Ottawa $(\mathrm{ON})$ : The Organization; 2003. Available: www.naho.ca/documents/fnc/english /FNC SummaryofNAHOPoll.pdf (accessed 2011 Jan. 12).

12. Northwest Territories Health and Social Service. Cancer in the Northwest Territories 1990-2000: a descriptive report. Yellowknife (NWT): the Service; 2003. Available: www.hlthss.gov.nt.ca/english /publications/pubresult.asp?ID=121 (accessed 2011 Jan. 12).

13. McDermott S. Cervical cancer screening in the NWT. Epi North 2002; $14: 14-8$.

14. Louchini R, Beaupré M. Cancer incidence and mortality among Aboriginal people living on reserves and northern villages in Quebec, 1988-2004. Int J Circumpolar Health 2008;67:445-451

Affiliations: From the Centre for Communicable Diseases and Infection Control (Demers, Remes, Dinner, Wong, Jayaraman) and the Centre for Chronic Disease Prevention and Control (Onysko), Public Health Agency of Canada, Ottawa, Ont.; the Department of Community Health Sciences (Demers, Kliewer), University of Manitoba; the Department of Epidemiology and Cancer Registry (Demers, Kliewer), CancerCare Manitoba, Winnipeg, Man.; Cancer Control Research (Kliewer), British Columbia Cancer Agency, Vancouver, BC; the Departments of Infectious Diseases (Wong) and Epidemiology and Community Medicine (Jayaraman), University of Ottawa, Ottawa, Ont.

Contributors: All of the authors contributed to the conception and design of this article, as well as to the drafting or revising of the article. All of the authors approved the final version submitted for publication.

Acknowledgements: The views expressed in this article are those of the authors and do not necessarily reflect the views of the Public Health Agency of Canada. The authors thank Christina Jensen and Martine Dubuc from the First Nations and Inuit Health Branch for their comments. 